\title{
Using nod genes control system to create rhizospheric microorganisms with regulated gene expression
}

Chubukova O.V, Vershinina Z.R, Matnyazov R.T., Baymiev Al. Kh.

Institute of Biochemistry and Genetics - Subdivision of the Ufa Federal Research Centre of the Russian Academy of Sciences,

Ufa, Russia

E-mail: chubukova@bk.ru

Key message. Inducible vector containing the full-sized nodD gene and the promoter region of the nod-box under the control of which was cloned the gfp gene was constructed. Modified bacteria R. galegae in which the synthesis of GFP protein was activated by plant flavonoids were obtained.

Keywords: Rhizobia, nod-box, growth-promoting associations

Rhizobia are soil nodule bacteria that can to establish a nitrogen-fixing symbiosis with legumes plants. To date, rhizobia are widely used as biofertilizer in agriculture.

The aim of the work was to obtain strains of nodule bacteria with controlled inclusion of target genes, which are induced by plant root secretions.

Methods of molecular cloning were used to obtain genetic engineering constructs. The resulting vectors tested by PCR and DNA sequencing. Expression of the target gene was confirmed by Western blot. Fluorescent-tagged bacteria were observed using a BioZero Analyzer microscope (Keyence, Japan).

The nod genes in the rhizobia genomes formed are cassette and in $R$. leguminosarum the nodD genes are located adjacent to the nod-box promoter region and have different coding directions. The nodD protein is activated by plant flavonoids and then induce nod-box promoter. We amplified DNA fragment of $R$. leguminosarum containing the full-size nodD gene and the nodbox promoter. Then, the $g f p$ reporter gene was cloned into the pTurboGFP vector under the control of the nod-box promoter. Further, the fragment containing the nodD + nod-box promoter $+g f p$ region was cloned into the vector pJN105. The resulting construct pJN105nodDGFP was introduced into rhizobia $R$. galegae 0702 by transformation. The transformed and control strains of $R$. galegae were treated by the following plant flavonoids: apigenin, quercetin, taxifolin, genistein, hesperidin. Western blot analysis and fluorescence microscopy showed that each of these flavonoids induced the expression of the target gene with different levels, which led to the accumulation of GFP protein in the rhizobia cells. Further, on the basis of plasmid pJN105nodD, it is proposed to obtain various constructs for studying the conditions for activation of target genes. The ultimate goal of our research is to create a system for the specific inclusion of the synthesis of various growth-promoting and protective substances in rhizosphere microorganisms induced by plant root secretions.

This work was supported by the grant of the RFBR 18-34-20004 mol_a_ved.

\section{Использование Nod системы ризобий для создания ризосферных микроорганизмов с регулируемой экспрессией генов}

Чубукова О.В., Вериинина З.Л., Матниязов Р.Т., Баймиев Ал.Х.

Институт биохимии и генетики - обособленное структурное подразделение Федерального государственного бюджетного научного учреждения Уфимского федерального исследовательского центра Российской академии наук, Уфа, Россия.

\begin{abstract}
Аннотация. Создана регулируемая векторная конструкция, содержащая полноразмерный ген подD и промоторный участок nod-box R. leguтіпоsarum, под контролем которого был клонирован ген gfр. Были получены модифицированные бактерии R. galegae, в которых синтез GFP белка активировался растительными флавоноидами.

Ключевые слова: ризобии, nоd-box, ростостимулирующие ассоциициии

Ризобии - это почвенные клубеньковые бактерии, которые способны вступать в азотфиксирующий симбиоз с бобовыми растениями. В настоящее время ризобии нашли широкое применение в качестве биоудобрений в сельском хозяйстве.

Целью работы являлось получение штаммов клубеньковых бактерий с регулируемым включением целевых генов, которое индуцируются корневыми выделениями растений.

Для получения генно-инженерных конструкций были использованы методы молекулярного клонирования. Полученные плазмиды проверяли ПЦР, секвенированием ДНК. Экспрессию целевого гена подтверждали вестерн-блот с антителами к GFP белку. Флуоресцентно окрашенные бактерии наблюдали с помощью микроскопа BioZero Analyzer (Keyence, Япония).

Nod гены в геномах ризобий расположены компактно, и у $R$. leguminosarum гены nodD расположены по соседству с промоторным участком nod-box и при этом имеют разное направление кодирования. Индуктором промотора nod-box является продукт гена $\operatorname{nod} D$, активированный растительными флавоноидами. Нами был амплифицирован фрагмент ДНК $R$. leguminosarum, содержащий полноразмерный ген nodD и промотор nod-box. Затем в вектор рTurboGFP под контролем промотора nod-box был клонирован репортерный ген gfp. Далее, фрагмент, содержащий участок nodD+промотор nod$b o x+g f p$ был переклонирован в плазмиду широкого круга хозяев pJN105. Полученной конструкцией pJN105nodDGFP были трансформированы ризобии $R$. galegae 0702. Трансформированный и контрольный штаммы $R$. galegae были индуцированы следующими растительными флавоноидами: апигенин, кверцитин, таксифолин, генистеин, гесперидин. Вестерн-блот анализ и флуоресцентная микроскопия показали, что в той или иной степени каждый из указанных флавоноидов индуцировал экспрессию целевого гена, что приводило к накоплению в клетках ризобий GFP белка. Далее на основе плазмиды pJN105nodD предполагается получение различных конструкций для изучения условий активации целевых генов. Конечной целью наших исследований является создание системы специфического включения синтеза различных ростостимулирующих и защитных веществ у ризосферных микроорганизмов, индуцируемого корневыми выделениями растений.
\end{abstract}

Данная работа была выполнена при финансовой поддержке гранта РФФИ 18-34-20004 мол_а_вед. 